\title{
Possible Relationship between Basal-Like Breast Carcinoma and Age*
}

\author{
Aline Schmitt Polidoro ${ }^{a}$ Rozany Mucha Dufloth ${ }^{b}$ Daniella S. Couto Vieira \\ Luiz Carlos Zeferino ${ }^{c}$ Fernando Schmitt ${ }^{\mathrm{d}}$ \\ a Department of Pathology, University of Campinas (UNICAMP), Campinas, São Paulo, \\ ${ }^{b}$ Department of Pathology, Federal University of Santa Catarina, Florianópolis, Santa Catarina, \\ ' Department of Obstetrics and Gynecology, Faculty of Medical Sciences, University of Campinas (UNICAMP), Campinas, São Paulo, Brazil \\ ${ }^{d}$ Medical Faculty of Porto University and Institute of Pathology and Molecular Immunology, Porto University, Porto, Portugal
}

\section{Key Words}

Breast carcinoma - Estrogen receptor .

Biological tumor markers · HER2 protein · Age group

\section{Summary}

Introduction: Estrogen receptor expression is lower in breast carcinoma of women $\leq 45$ years compared to women $\geq 65$ years of age, which may imply a higher frequency of basal-like breast carcinomas in younger women. This study evaluated whether there is any difference in the frequency of basal-like phenotype and estrogen receptor (ER)-/HER2- invasive breast carcinomas between women of these 2 different age groups. Patients and Methods: A total of 151 women aged $\leq 45$ years or $\geq 65$ years with invasive breast carcinomas were evaluated using tissue microarray, and classified into the following phenotypes: luminal A (ER+/HER2-), luminal B (ER+/HER2+), HER2 overexpression (ER-/HER2+), and basal-like (ER-/HER2- and expressing at least 1 of the basal markers p63, CK5 and/or P-cadherin). Results: ER-/HER2- carcinomas were twice as frequent in women aged $\leq 45$ years $(p=0.0247)$. However, when the basal-like phenotype was compared with all the other phenotypes grouped together, no statistically significant difference was found ( $p=0.0854)$. Conclusions: ER-/HER2- carcinomas were more frequent in younger women compared to all the other phenotypes grouped together. An international consensus will be necessary to establish which markers should be used to define basal-like phenotype.

*Authors' contributions: ASP, RD and LZ designed the study; RD and ASP wrote the research project; RD, DV and FS are medical doctors responsible for patients and IHC; LZ, RD and ASP analysed the data and prepared manuscript draft; $\mathrm{LZ}$ revised the manuscript critically.

\section{Schlüsselwörter}

Mammakarzinom - Östrogenrezeptor .

Biologische Tumormarker · HER2-Protein · Altersgruppe

\section{Zusammenfassung}

Hintergrund: Östrogenrezeptoren sind weniger exprimiert in Mammakarzinomen von Patientinnen bis zu einem Alter von 45 Jahren im Vergleich zu Frauen ab 65 Jahren, weshalb Karzinome des basalen Phänotyps häufiger in jüngeren Frauen zu erwarten wären. Das Ziel dieser Studie war es, die Häufigkeit des basalen Phänotyps und der Mammakarzinome ohne Expression von Östrogenrezeptoren (R) und HER2 in beiden Altersgruppen zu vergleichen. Patienten und Methoden: Die Karzinome von 151 Patientinen wurden anhand eines Microarrays analysiert und wie folgt klassifiziert: luminal A (R+/HER2-), luminal $B(\mathrm{R}+/ \mathrm{HER} 2+)$, HER2 überexprimiert (R-/HER2+) und basaler Phänotyp (R-/HER2- und zugleich Expression für mindestens einen der Marker p63, CK5 und/oder P-cadherin). Ergebnisse: R-/HER2- Karzinome waren doppelt so häufig in der Gruppe von Frauen bis zu 45 Jahren ( $p=0,0247)$. Jedoch beim Vergleich des basalen Phänotyps mit allen anderen diagnostischen Kategorien konnte keine statistisch signifikante Differenz gefunden werden ( $p=0,0854)$. Schlussfolgerung: R-/HER2- Karzinome wurden häufiger in jungen Frauen gefunden als alle anderen diagnostischen Kategorien zusammengefasst. Ein internationaler Konsens zur Definition des basalen Phänotyps anhand der biologischen Marker ist notwendig.

\section{KARGER}

Fax +497614520714

Information@Karger.de

www.karger.com (c) 2009 S. Karger GmbH, Freiburg

Accessible online at:

www.karger.com/brc 


\section{Introduction}

Breast carcinoma is a heterogeneous disease [1-3] the diversity of which is clear from evaluation of its gene expression. Classification into phenotypes based on the expression of certain proteins is of fundamental importance, since it is correlated with different prognosis [2-7]. Among the known phenotypes, basal-like breast carcinoma is characterized by the absence of target therapies, since the genes that are responsible for its aggressiveness are not yet completely understood [8] and because no international consensus has yet been drawn up with respect to an ideal set of markers that would immunohistochemically define its status [9].

Among the factors that affect the occurrence of breast carcinoma phenotypes, age at diagnosis is one of the most important $[2,3,10]$. Younger women tend to develop neoplasias with more aggressive characteristics [11], more often with a high histological grade and absence of estrogen receptor (ER) expression [12-14], features present on the basal-like carcinomas $[15,16]$. In addition, young women exhibit more frequently mutations, with early age at onset generally being considered one of the indicators of genetic susceptibility to breast carcinoma $[12,17]$, which is also compatible with basal-like carcinomas, since this is the type most often found in women with BRCA1 mutations [18]. Therefore, it would be reasonable to hypothesize that more cases of basal-like breast carcinoma may occur in younger women.

Recent studies have shown that in African American populations, there are peaks in the incidence of triple-negative carcinomas (ER-/ progesterone receptor-negative (PR-) / HER2-) in women under 35 years of age and in the 51-65 year age group [2], the highest prevalence being found in women under 35 years of age $[2,3]$. In women not selected by ethnic group, there is a greater likelihood of these same triple-negative carcinomas rather than the other subtypes being diagnosed in women of less than 40 years of age [10]. Nevertheless, triple-negative breast carcinomas are known to represent a more heterogeneous group of tumors than those with basal-like phenotype, and include both basal and non-basal tumors $[19,20]$.

There is great interest in comparing women of 45 years of age or less with those aged 65 years or more to establish whether the higher rate of ER- neoplasias in the younger age group $[13,21]$ correlates with a higher rate of the basal-like phenotype. For this reason, the present study evaluated ER-/ HER2- carcinomas based on the study carried out by Carey et al. [22]. Basal-like phenotype, defined in this study as ER-/ HER2 - carcinomas expressing at least 1 basal marker (p63, CK5, or P-CAD), were also evaluated, since the specificity conferred by basal markers is fundamental when selecting patients for BRCA1 mutation testing [23] and when it is necessary to indentify poor prognosis cases [20].

\section{Patients and Methods}

\section{Patients}

Clinical information, pathology reports, slides, and paraffin blocks were obtained following the informed consent of patients, under the guidelines and approval of the Internal Review Boards of the School of Medical Sciences of UNICAMP and UFSC, and the National Committee for Ethics in Research (CONEP). This study investigated a consecutive series of 151 cases of invasive breast carcinoma presenting between 1994 and 2004 at the Teaching Hospital of the Federal University of Santa Catarina (UFSC), Santa Catarina, Brazil, and presenting between 2002 and 2004 at the Breast Cancer Outpatient Clinic of the Women's Comprehensive Healthcare Center (Centro de Atenção Integral à Saúde da Mulher, CAISM/UNICAMP), Campinas, São Paulo, Brazil, and at the Institute of Pathology and Molecular Immunology (IPATIMUP) of the University of Porto, Portugal. The study population consisted of women aged $\leq 45$ years or $\geq 65$ years.

\section{Tissue Microarray Construction}

Tissue microarrays (TMAs) were prepared as previously described [1, 24]. For each tumor, a representative tumor section was selected from a hematoxylin and eosin ( $\mathrm{H}$ and $\mathrm{E})$-stained section of the donor block. Core cylinders with a diameter of $2 \mathrm{~mm}$ each were punched from this area using a thin-walled stainless steel tube and deposited into a recipient paraffin block. TMA sections were mounted on charged slides (SuperFrost ${ }^{\text {TMPlus, }}$ Thermo Fisher Scientific Inc., Karlsruhe, Germany). H and E-stained TMA sections were used for reference histology.

\section{Immunohistochemistry}

Immunohistochemistry, carried out using ER, HER2, p63, CK5, and Pcadherin markers on formalin-fixed, paraffin-embedded samples, was performed as previously described [1,24]. Basal markers were analyzed in all tumors. Samples were then classified into the following phenotypes: i) luminal A: ER+/HER2-, ii) luminal B: ER+/HER2+, iii) HER2 overexpression: ER-/HER2+, and iv) basal-like carcinoma [2, 3, 5, 15, 18]. In a series of 70 tumors [4, 16], Carey et al. [22] reported that a simple ER and HER2 scoring method was capable of correctly identifying 94\% of cases of basal-like breast carcinoma; therefore, in the present study, the presence of the basal-like phenotype was investigated in both ER-/ HER2 - carcinomas and in ER-/HER2- carcinomas that were positive for at least 1 basal marker (p63 and/or CK5 and/or P-cadherin) [1]. Two pathologists evaluated immunohistochemical staining.

\section{Statistical Analysis}

The $\chi^{2}$ contingency test was used for categorical variables to determine differences between groups. A p value $<0.05$ was considered representative of a statistically significant difference. The StatView software program, version 8.2 (SAS Institute, Cary, NC, USA) was used to perform these analyses.

\section{Results}

ER-/HER2 - carcinomas were more frequent in women $\leq 45$ years of age $(29.3 \%)$ than in women $\geq 65$ years of age $(13.6 \%)$ when compared to all the other phenotypes grouped together as non-basal group: luminal A, luminal B, and HER2 overexpression $(\mathrm{p}=0.0247)$ (table 1$)$. Therefore, ER-/HER2- carcinomas were twice as common in women in the younger age group. Nevertheless, when the non-basal group was compared with the basal phenotype group using the ER-/HER- carcinomas that expressed at least 1 of the basal markers, there was 
Table 1. Distribution of ER-/HER2- carcinomas compared to all other (non-basal) phenotypes grouped together, according to age group $\left(\chi^{2}\right.$ test $)$

\begin{tabular}{llll}
\hline $\begin{array}{l}\text { Group of } \\
\text { carcinomas }\end{array}$ & $\begin{array}{l}\text { Distribution according to } \\
\text { age group, } \mathrm{n}(\%)\end{array}$ & $\mathrm{p}$ \\
\cline { 2 - 3 } & $\leq 45$ years & $\geq 65$ years & \\
\hline Non-basal & $53(70.7)$ & $57(86.4)$ & 0.0247 \\
ER-/HER2- & $22(29.3)$ & $9(13.6)$ & \\
Indeterminate & 4 & 6 & \\
Total & 79 & 72 & \\
\hline
\end{tabular}

$\mathrm{ER}=$ Estrogen receptor

Table 2. Distribution of basal phenotype compared to all other (nonbasal) phenotypes grouped together, according to age group ( $\chi^{2}$ test)

\begin{tabular}{llll}
\hline $\begin{array}{l}\text { Group of } \\
\text { carcinomas }\end{array}$ & $\begin{array}{l}\text { Distribution according to age } \\
\text { group, } \mathrm{n}(\%)\end{array}$ & $\mathrm{p}$ \\
\cline { 2 - 3 } & $\leq 45$ years & $\geq 65$ years & \\
\hline Non-basal & $53(81.5)$ & $57(91.9)$ & 0.0854 \\
Basal & $12(18.5)$ & $5(8.1)$ & \\
Indeterminate & 14 & 10 & \\
\cline { 2 - 3 } Total & 79 & 72 & \\
\hline
\end{tabular}

Table 3. Frequency of breast carcinoma phenotypes according to age group $\left(\chi^{2}\right.$ test) and basal phenotype

\begin{tabular}{llll}
\hline Carcinoma phenotype & $\begin{array}{l}\text { Frequency according to age } \\
\text { group, } \mathrm{n}(\%)\end{array}$ & \\
\cline { 2 - 3 } & $\leq 45$ years & $\geq 65$ years & \\
\hline Luminal A & $33(50.8)$ & $36(58.1)$ & \\
Luminal B & $10(15.4)$ & $9(14.5)$ & 0.3650 \\
HER2 overexpression & $10(15.4)$ & $12(19.4)$ & \\
Basal & $12(18.5)$ & $5(8.1)$ & \\
Indeterminate & 14 & 10 & \\
Total & 79 & 72 &
\end{tabular}

Table 4. Frequency of breast carcinoma phenotype according to age group ( $\chi^{2}$ test) and ER-/HER2- carcinomas

\begin{tabular}{llll}
\hline Carcinoma phenotype & $\begin{array}{l}\text { Frequency according to age } \\
\text { group, } \mathrm{n}(\%)\end{array}$ & \\
\cline { 2 - 3 } & $\leq 45$ years & $\geq 65$ years & \\
\hline Luminal A & $33(44.0)$ & $36(54.5)$ & 0.1535 \\
Luminal B & $10(13.3)$ & $9(13.6)$ & \\
HER2 overexpression & $10(13.3)$ & $12(18.2)$ & \\
ER-/HER2- & $22(29.3)$ & $9(13.6)$ & \\
Indeterminate & 4 & 6 & \\
Total & 79 & 72 \\
\hline
\end{tabular}

$\mathrm{ER}=$ Estrogen receptor. no statistically significant difference between the 2 age groups with respect to the frequency of the basal-like phenotype $(\mathrm{p}=0.0854)$ (table 2). Evaluation of luminal A, luminal B, and HER2 overexpression carcinoma subtypes analyzed alone in each age group and compared to the frequencies of ER-/ HER2 - carcinomas and basal-like phenotype, showed no statistically significant difference between the frequencies of the different phenotypes when analyzed individually in the 2 age groups (tables 3 and 4).

\section{Discussion}

In this study, ER-/HER2- carcinomas were more common in women $\leq 45$ years of age than in women $\geq 65$ years of age when compared to all the other phenotypes grouped together $(p=0.0247)$. Despite the fact that ER-/HER2- carcinomas were twice as common in the younger group of women and that Carey et al. [22] had reported that using only these 2 markers, ER and HER2, it was possible to correctly identify the majority (94\%) of basal-like breast carcinomas, when the immunohistochemical profile ER-/ HER2- was applied to the present study together with at least 1 positive basal marker (p63, CK5, or P-cadherin), there was no statistically significant difference between the 2 age groups for this subtype compared to the other phenotypes $(\mathrm{p}=0.0854)$. Therefore, it was concluded that the inconsistency in the definitions of basal-like breast carcinoma has significantly affected the results obtained in the various studies $[9,25]$; hence, it is clear that there is a need to define an immunohistochemical profile characterizing this phenotype, standardizing the studies [9], and making comparison possible between different age groups and different ethnic groups. This is particularly true since it was found that basal-like breast carcinomas, principally those defined by immunohistochemistry, are more heterogeneous than previously believed [9, 26].

Although 2 studies have specifically evaluated groups of women aged $\leq 45$ years and $\geq 65$ years $[13,21]$, emphasizing the higher frequency of ER-carcinomas in the younger women, no study has yet clarified whether this is correlated to a greater frequency of basal-like breast carcinomas in women $\leq 45$ years of age. Currently available knowledge on the relationship between age at diagnosis and breast carcinoma phenotypes is still being constructed, since the studies that have been published up to this date have used different immunohistochemical profiles; moreover, they often evaluate specific ethnic groups and frequently divide the women into groups according to their menopausal status $[2,3,5,7$, $10]$.

Ihemelandu et al. [2] found a greater rate of triple-negative carcinomas (ER-/PR-/HER2-) in African American women aged $\leq 35$ years. In women not selected according to ethnic group, Bauer et al. [10] also concluded that those with triple- 
negative carcinomas were significantly more likely to be under 40 years of age. Carey et al. [5], who associated CK5/6 and/or epidermal growth factor receptor (EGFR) expression with triple-negative carcinomas to define basal-like phenotype, observed that in the group of African American women there was a greater rate of basal-like phenotype compared to the other phenotypes in premenopausal women compared to postmenopausal women; however, in non-African Americans, there was no difference in basal-like phenotype expression between women $<50$ and $>50$ years of age. The complexity of the debate is clear from the observation that even in these 2 large, population-based studies $[5,10]$ that differ with respect to whether or not CK5/6 and/or EGFR expression are necessary for triple-negative carcinomas to be considered as being of basal-like phenotype, there is discord in their conclusions with respect to the evaluation of African American women: Carey et al. [5] reported a higher rate of basal-like carcinomas among premenopausal women, whereas Ihemelandu et al. [2] affirmed that menopausal status had no significant effect on the prevalence of breast carcinoma phenotypes.

Fulford et al. [7] evaluated high-grade breast carcinomas and reported a mean age of 49.9 years for the occurrence of basal-like (CK14+) carcinomas versus 53.9 years for the occurrence of all the other phenotypes grouped together as nonbasal-like (CK14-) carcinomas. Despite being statistically significant, this difference showed that by defining basal-like phenotype according to CK14 expression, the mean age at which basal-like phenotype occurred was just slightly lower than that of patients with other high-grade neoplasias [7]. Tang et al. [27] reported that 4 principal classifications are currently used in the literature to differentiate basal-like from non-basal-like carcinomas, and concluded that these classifications are not interchangeable. Therefore, it would not be correct to compare the frequencies of the breast carcinoma phenotypes found in different age groups between studies that use different immunohistochemical classifications to define basal-like carcinomas. Since there are no studies available that have evaluated the frequency of breast carcinoma phenotypes and that use ER-/HER2- carcinomas or the ER-/ HER2- immunohistochemical profile plus at least 1 positive basal marker (p63, CK5, or P-cadherin) to define basal-like carcinomas in women $\leq 45$ years of age and $\geq 65$ years of age, comparison between the results of this study and those published in the literature is impossible.

Another finding of this study was the percentage of indeterminate cases that were ER-, HER2-, p63-, CK5-, and P-cadherin- and constituted $17.7 \%$ of the carcinomas in women $\leq 45$ years of age and $13.8 \%$ of those in women $\geq 65$ years. In the study carried out by Nielsen et al. [4], the neoplasias considered indeterminate (ER-, HER2-, CK5/6-, and EGFR-) corresponded to $22 \%$ of all the cases studied, whereas Kim et al. [28] reported a rate of $15.9 \%$ (ER-, PR-, HER2-, CK5-, CK14-, EGFR-, and C-kit-). This group needs to be identified, since Nielsen et al. [4] showed that, as in the group with basal-like carcinomas, this group was also found to have a poorer prognosis. Moreover, as reported by these investigators, some of these cases would be neoplasias that may have been allocated to this category as a result of technical failures or may be normal breast-like carcinomas [4]. Normal breast-like carcinomas are not usually investigated in studies in which breast carcinoma phenotypes are evaluated by immunohistochemistry, and represent a third phenotype of the ER-carcinoma category, after basal-like and HER2 overexpression [6].

Indeterminate cases may also be basal-like carcinomas that fail to express any of the 3 basal markers proposed in the present study; however, they may express other markers such as EGFR, vimentin, or CK14. This fact is notable since the ER-/HER2- plus CK5/6+ and/or EGFR+ profile was found to result in sensitivity of $55 \%[9,16]$ to $76 \%$ [4] for the identification of basal-like carcinomas, with specificity of $100 \%$ [4, $9,16]$. Therefore, by analyzing the percentages of basal-like carcinomas in accordance with their gene expression profile, many remained specifically unidentified $[4,9,16]$. On the other hand, the specificity of $100 \%$ for identifying a basal-like carcinoma is fundamental when considering the selection of patients for BRCA1 mutation testing [23].

With so many studies comparing different immunohistochemical profiles to define basal-like breast carcinoma, each one affecting the proportion of cases reported for specific age groups and considering the influence of ethnic groups, our findings lead us to conclude that a better established set of immunohistochemical markers must be defined for the classification of basal-like carcinomas $[9,25]$. When this has been validated, it will enable more appropriate comparisons to be made between the different studies, evaluating the true effect of the patient's age on the occurrence of basal-like breast carcinoma in women of different ethnic groups and in women not selected according to ethnic group, thus leading to greater understanding with respect to why prognoses are poorer in specific age groups and how basal-like phenotype affects prognosis [7].

\section{Conclusions}

When compared with all the other phenotypes grouped together, ER-/HER2- carcinomas were more frequent in younger women $\leq 45$ years of age than in women $\geq 65$ years of age. This was not found when ER-/HER2- carcinomas plus at least 1 positive basal marker (p63, CK5, P-cadherin) were considered as a basal-like phenotype. Therefore, a consensus of immunohistochemical markers should be established to consistently identify basal-like carcinomas, permitting more appropriate comparisons between the different studies [9, 25 ] and clarifying the true effect of the patient's age on the occurrence of basal-like breast carcinoma. 


\section{Acknowledgments}

We thank all research subjects for their cooperation. The authors also thank Prof. Dr. Konradin Metze (FCM/UNICAMP) for revision of the German section of the manuscript. This work was partially supported by grants from CAPES, the Ministry of Education of Brazil, BEX2448/02, the Luso-American Development Foundation (FLAD), ref. L-V-172/2002, the National Counsel for Scientific Development and Tech- nology (CNPq), Brazil (Aline Schmitt Polidoro, CNPq fellow, Brazil), and the Foundation for the Support of Scientific Research, Santa Catarina, protocol FCTP 1703/000.

\section{Conflict of Interest}

The authors declare no conflict of interests.

\section{References}

1 Matos I, Dufloth R, Alvarenga M, Zeferino LC, Schmitt F: p63, cytokeratin 5, and P-cadherin: three molecular markers to distinguish basal phenotype in breast carcinomas. Virchows Arch 2005;447:688694

2 Ihemelandu CU, Leffall LD Jr, Dewitty RL, Naab TJ, Mezghebe HM, Makambi KH, Adams-Campbell L, Frederick WA: Molecular breast cancer subtypes in premenopausal and postmenopausal African-American women: age-specific prevalence and survival. J Surg Res 2007;143:109-118.

3 Ihemelandu CU, Leffall LD Jr, Dewitty RL, Naab TJ, Mezghebe HM, Makambi KH, Adams-Campbell L, Frederick WA: Molecular breast cancer subtypes in premenopausal African-American women, tumor biologic factors and clinical outcome. Ann Surg Oncol 2007;14:2994-3003.

$\checkmark 4$ Nielsen TO, Hsu FD, Jensen K, Cheang M, Karaca $\mathrm{G}, \mathrm{Hu} \mathrm{Z}$, Hernandez-Boussard T, Livasy C, Cowan D, Dressler L, Akslen LA, Ragaz J, Gown AM, Gilks CB, van de Rijn M, Perou CM: Immunohistochemical and clinical characterization of the basal-like subtype of invasive breast carcinoma. Clin Cancer Res 2004;10:5367-5374.

5 Carey LA, Perou CM, Livasy CA, Dressler LG, Cowan D, Conway K, Karaca G, Troester MA, Tse CK, Edmiston S, Deming SL, Geradts J, Cheang MC, Nielsen TO, Moorman PG, Earp HS, Millikan RC: Race, breast cancer subtypes, and survival in the Carolina Breast Cancer Study. JAMA 2006;295: 2492-2502.

6 Rakha EA, El-Sayed ME, Green AR, Lee AH, Robertson JF, Ellis IO: Prognostic markers in triple-negative breast cancer. Cancer 2007;109:25-32.

7 Fulford LG, Reis-Filho JS, Ryder K, Jones C, Gillett CE, Hanby A, Easton D, Lakhani SR: Basallike grade III invasive ductal carcinoma of the breast: patterns of metastasis and long-term survival. Breast Cancer Res 2007;9:R4.

$\checkmark$ Yehiely F, Moyano JV, Evans JR, Nielsen TO, Cryns VL: Deconstructing the molecular portrait of basal-like breast cancer. Trends Mol Med 2006;12: 537-544.

9 Fadare O, Tavassoli FA: The phenotypic spectrum of basal-like breast cancers: a critical appraisal. Ady Anat Pathol 2007;14:358-373.
10 Bauer KR, Brown M, Cress RD, Parise CA, Caggiano V: Descriptive analysis of estrogen receptor (ER)-negative, progesterone receptor (PR)-negative, and HER2-negative invasive breast cancer, the so-called triple-negative phenotype: a population-based study from the California cancer Registry. Cancer 2007;109:1721-1728.

11 El Saghir NS, Seoud M, Khalil MK, Charafeddine M, Salem ZK, Geara FB, Shamseddine AI: Effects of young age at presentation on survival in breast cancer. BMC Cancer 2006;6:194.

12 Figueiredo JC, Ennis M, Knight JA, McLaughlin JR, Hood N, O'Malley F, Andrulis IL, Goodwin PJ: Influence of young age at diagnosis and family history of breast or ovarian cancer on breast cancer outcomes in a population-based cohort study. Breast Cancer Res Treat 2007;105:69-80.

13 Talley LI, Grizzle WE, Waterbor JW, Brown D, Weiss H, Frost AR: Hormone receptors and proliferation in breast carcinomas of equivalent histologic grades in pre- and postmenopausal women. Int J Cancer 2002;98:118-127.

14 Eerola H, Heikkilä P, Tamminen A, Aittomäki K, Blomqvist C, Nevanlinna H: Relationship of patients' age to histopathological features of breast tumours in BRCA1 and BRCA2 and mutationnegative breast cancer families. Breast Cancer Res 2005;7:R465-469.

15 Sørlie T, Perou CM, Tibshirani R, Aas T, Geisler S, Johnsen H, Hastie T, Eisen MB, van de Rijn M, Jeffrey SS, Thorsen T, Quist H, Matese JC, Brown PO, Botstein D, Eystein Lønning P, Børresen-Dale AL: Gene expression patterns of breast carcinomas distinguish tumor subclasses with clinical implications. Proc Natl Acad Sci U S A 2001;98: 10869-10874.

16 Livasy CA, Karaca G, Nanda R, Tretiakova MS, Olopade OI, Moore DT, Perou CM: Phenotypic evaluation of the basal-like subtype of invasive breast carcinoma. Mod Pathol 2006;19:264-271.

17 Musolino A, Bella MA, Bortesi B, Michiara M, Naldi N, Zanelli P, Capelletti M, Pezzuolo D, Camisa R, Savi M, Neri TM, Ardizzoni A: BRCA mutations, molecular markers, and clinical variables in early-onset breast cancer: a populationbased study. Breast 2007;16:280-292.
18 Sorlie T, Tibshirani R, Parker J, Hastie T, Marron JS, Nobel A, Deng S, Johnsen H, Pesich R, Geisler S, Demeter J, Perou CM, Lønning PE, Brown PO Børresen-Dale AL, Botstein D: Repeated observation of breast tumor subtypes in independent gene expression data sets. Proc Natl Acad Sci U S A 2003; 100:8418-8423

19 Bertucci F, Finetti P, Cervera N, Esterni B, Hermitte F, Viens P, Birnbaum D: How basal are triple-negative breast cancers? Int J Cancer 2008;123: 236-240

20 Cheang MC, Voduc D, Bajdik C, Leung S, McKinney S, Chia SK, Perou CM, Nielsen TO: Basal-like breast cancer defined by five biomarkers has superior prognostic value than triple-negative phenotype. Clin Cancer Res 2008;14:1368-1376.

21 Anders CK, Acharya CR, Hsu DS, Broadwater G, Garman K, Foekens JA, Zhang Y, Wang Y, Marcom K, Marks JR, Mukherjee S, Nevins JR, Blackwell KL, Potti A: Age-specific differences in oncogenic pathway deregulation seen in human breast tumors. PLoS ONE 2008;3:e1373.

22 Carey LA, Dees EC, Sawyer L, Gatti L, Moore DT, Collichio F, Ollila DW, Sartor CI, Graham ML, Perou CM: The triple negative paradox: primary tumor chemosensitivity of breast cancer subtypes. Clin Cancer Res 2007;13:2329-2334.

23 Da Silva L, Clarke C, Lakhani SR: Demystifying basal-like breast carcinomas. J Clin Pathol 2007;60: 1328-1332.

24 Dufloth R, Matos I, Schmitt FC, Zeferino LC: Tissue microarrays for testing basal biomarkers in familial breast cancer cases. Sao Paulo Med J 2007; 125:226-230.

25 Rakha EA, Reis-Filho JS, Ellis IO: Basal-like breast cancer: a critical review. J Clin Oncol 2008; 26:2568-2581.

26 Kreike B, van Kouwenhove M, Horlings H, Weigelt B, Bartelink H, Van de Vijver MJ: Gene expression profiling and histopathological characterization of triple negative/basal-like breast carcinomas. Breast Cancer Res 2007:9:R65

27 Tang P, Wang J, Bourne P: Molecular classifications of breast carcinoma with similar terminology and different definitions: are they the same? Hum Pathol 2008;39:506-513.

28 Kim MJ, Ro JY, Ahn SH, Kim HH, Kim SB, Gong G: Clinicopathologic significance of the basal-like subtype of breast cancer: a comparison with hormone receptor and Her2/neu-overexpressing phenotypes. Hum Pathol 2006;37:1217-1226. 